\title{
Deletion of 1.8-kb mRNA of Marek's disease virus decreases its replication ability but not oncogenicity
}

\author{
Aijun Sun ${ }^{1 \dagger}$, Yanpeng $\mathrm{Li}^{2 \dagger}$, Jingyan Wang ${ }^{1}$, Shuai Su${ }^{1}$, Hongjun Chen ${ }^{3}$, Hongfei Zhu², Jiabo Ding ${ }^{4 *}$, Zhizhong Cui ${ }^{{ }^{*}}$
}

\begin{abstract}
Background: The 1.8-kb mRNA was reported as one of the oncogenesis-related genes of Marek's disease virus (MDV). In this study, the bacterial artificial chromosome (BAC) clone of a MDV field strain GX0101 was used as the platform to generate mutant MDV to examine the functional roles of 1.8-kb mRNA.

Results: Based on the BAC clone of GX0101, the 1.8-kb mRNA deletion mutant GX0101 $\triangle(A+C)$ was constructed. The present experiments indicated that $G X 0101 \triangle(A+C)$ retained a low level of oncogenicity, and it showed a decreased replication capacity in vitro and in vivo when compared with its parent virus, GX0101. Further studies in vitro demonstrated that deletion of 1.8-kb mRNA significantly decreased the transcriptional activity of the bidirectional promoter between 1.8-kb mRNA and pp38 genes of MDV.

Conclusion: These results suggested that the 1.8-kb mRNA did not directly influence the oncogenesis but related to the replication ability of MDV.
\end{abstract}

\section{Background}

Marek's disease (MD) is a contagious lymphoproliferative disease of poultry caused by the highly oncogenic alphaherpesvirus, MDV, which is characteristic by mononuclear infiltration of peripheral nerves, irises, skin and other visceral tissues [1,2]. Among the 100 genes encoded by MDV, three genes including 1.8-kb mRNA, pp38 and meq were considered to be associated with oncogenicity of MDV serotype 1 , and they are also unique to MDV [3,4]. Previous studies suggested that meq is involved in lymphocyte transformation $[5,6]$, and pp38 is involved in early cytolytic infection in lymphocytes but not in the induction of tumors [7]. In addition, recent studies indicated that pp38 could also enhance the activity of the bi-directional promoter, which locates between pp38 and 1.8-kb mRNA in the long inverted repeat region of the viral genome, thus influence the replication capacity of the virus [8-10].

The 1.8-kb mRNA is unique to MDV and it has no homology with other groups of herpesviruses, and it received attention as a pathogenic determinant following

\footnotetext{
* Correspondence: dingjiabo@ivdc.gov.cn; zzcui@sdau.edu.cn

† Contributed equally

'Animal Science and Technology College, Shandong Agricultural University, Tai'an, Shandong 271018, China

${ }^{4}$ China Institute of Veterinary Drug Control, Beijing 100081, China Full list of author information is available at the end of the article
}

demonstration of the expansion of the 132-bp tandem repeats in the 1.8-kb mRNA region during attenuation of MDV. However, deletion of the two copies of the 132-bp repeat region in a pathogenic MDV demonstrated that the virus was still pathogenic [11]. The transcription map of 1.8-kb mRNA was published in 1989 [12], analysis of cDNA in the $1.8-\mathrm{kb}$ mRNA region identified two main open reading frames (ORFs) (ORF A and ORF C), and the proteins encoded by ORF A and $C$ could be detected in chicken embryo fibroblasts (CEF) infected with very virulent MDV as well as MDV-induced lymphoid cell lines [13]. Therefore, in the present study, ORF A and C were selected as the targets to study.

Recent progresses in BAC cloning and mutagenesis technology make it possible to identify specific genes important for MDV replication and oncogenesis. In earlier studies we cloned the full length genome of a virulent MDV strain, GX0101, into a bacterial artificial chromosome (BAC) and reconstituted the infectious virus, bac-GX0101. Studies in specific-pathogen-free (SPF) chickens showed that the virulence of bacGX0101 was higher than virulent MDV (vMDV) GA strain but lower than very virulent MDV (vvMDV) strain Md5, and there was no difference in growth ability and pathogenicity to birds when compared with its parental virus, GX0101 [14-16]. In this study, the BAC 
clone of GX0101 was used as the platform to generate mutant MDV to examine the functional roles of $1.8-\mathrm{kb}$ mRNA.

\section{Results \\ Verification of GX0101 $(A+C)$}

The deletion of the ORF $(A+C)$ was confirmed by PCR with purified GX0101 $\triangle 1(\mathrm{~A}+\mathrm{C})-\mathrm{BAC}$ and $\mathrm{GX0101} \Delta(\mathrm{A}+\mathrm{C})$ $\mathrm{BAC}$ as templates [16]. As shown in Figure 1, the deletion of both copies of ORF $(A+C)$ was confirmed by agarose gel electrophoresis of PCR. Then the GX0101 $\Delta(A+C)-B A C$ DNA was transfected into CEF for the rescue of GX0101 $\triangle$ $(A+C)$ virus. As shown in Figure 2, the plaque size of $\mathrm{GX0101} \Delta(\mathrm{A}+\mathrm{C})$ was smaller than that of GX0101 at $96 \mathrm{~h}$ after infected in fresh CEF cells.

\section{In vitro replication of $\mathrm{GX0101 \Delta (A+C)}$}

To determine whether the deletion of the 1.8-kb mRNA had any effect on GX0101 $\Delta(A+C)$ growth replication in vitro, the growth rate of $G X 0101 \Delta(A+C)$ virus was compared with that of GX0101. As shown in Figure 3, it was demonstrated that the recombinant virus GX0101 $(\mathrm{A}+\mathrm{C})$ exhibited a decreased replication ability in CEF compared with GX0101 at hours 72, 96, 120 and 144 post inoculation (p.i.) $(\mathrm{P}<0.05)$.

\section{Viremia levels of birds infected with $G \times 0101 \Delta(A+C)$ or GX0101 viruses}

The viremia levels in 10 birds from each group were determined on days 7, 14, 21 and 28 p.i. As indicated in Table 1, the viremia levels of GX0101 $\Delta(A+C)$-infected group were lower than that of GX0101 group during the whole experimental period, and significant differences were observed between the two groups on days 14, 21 and 28 p.i. $(\mathrm{P}<0.05)$.

\section{The effect of ORF $(A+C)$ on the activity of bi-directional} promoter

To determinate the activity of the bi-directional promoter, plasmids $\mathrm{pP}(\mathrm{pp} 38)-\mathrm{CAT}$ and $\mathrm{pP}(1.8-\mathrm{kb})$-CAT were used to transfect CEF monolayers. The results showed that the CAT expression level in uninfected CEF was very low, nearly 0 . The CAT activity in GX0101-CEF was higher than that in GX0101 $(\mathrm{A}+\mathrm{C})$-CEF $(\mathrm{P}<0.05)$ (Table 2). The results indicated that $1.8-\mathrm{kb}$ mRNA significantly affected the activity of the bi-directional promoter.

\section{Pathogenicity of GX0101 $\Delta(A+C)$ and GX0101}

To compare the pathogenicity of mutant virus with its parental virus, we examined the growth rates of infected birds. Both viruses strongly inhibited the growth rates of infected birds. As shown in Table 3, body weights of the birds inoculated with GX0101 $\Delta(\mathrm{A}+\mathrm{C})$ and GX0101 were

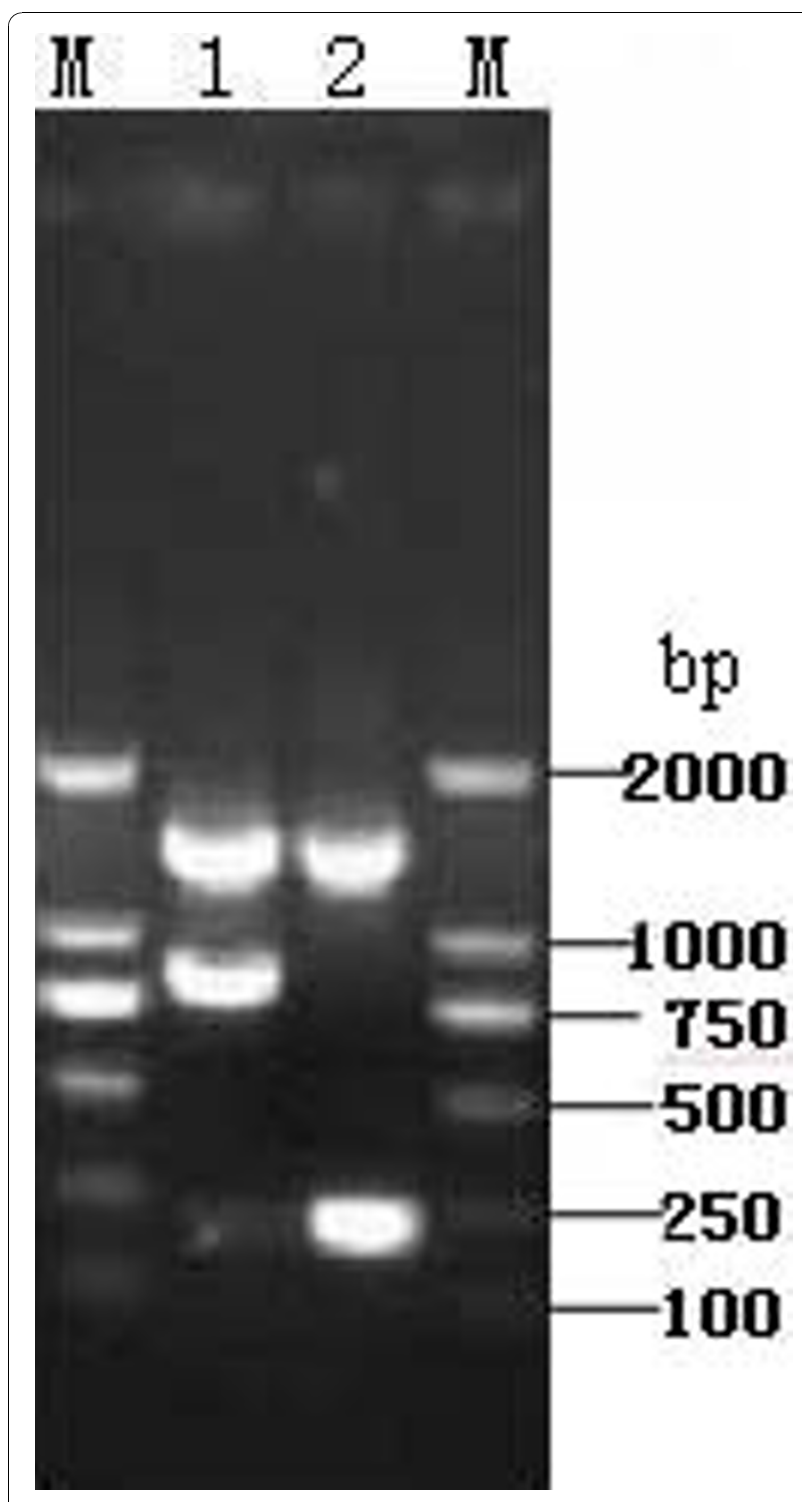

Figure 1 Analysis of PCR products of GX0101 $(A+C)-B A C$ DNA Lane M: DL2000 marker (TaKaRa Bio-Company, China); 1: the PCR

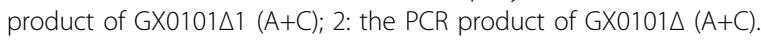
The bigger band demonstrated one of ORF $(A+C)$ was replaced by kana gene (in lanes 1 and 2). The smaller band demonstrated the deletion of the second $\operatorname{ORF}(A+C)$ in GX0101 $(A+C)-B A C D N A$ (in lane 2) compared to the smaller band that not deleted the second $\operatorname{ORF}(A+C)$ in GX0101 $\triangle 1(A+C)-B A C$ DNA (in lane 1).

significantly lower $(\mathrm{P}<0.05)$ than that of control birds from 5 weeks p.i. Between the two viruses, GX0101 showed stronger effects on growth rates of birds than GX0101 $\Delta(A+C)$ although the difference was not statistically significant $(\mathrm{P}>0.05)$.

During 120 days after challenged with the two viruses, $50 \%$ and $40 \%$ mortality were observed in groups inoculated with GX0101 or GX0101 $\Delta(\mathrm{A}+\mathrm{C})$, respectively. Furthermore, $22.5 \%$ and $12.5 \%$ of birds exhibited visceral 


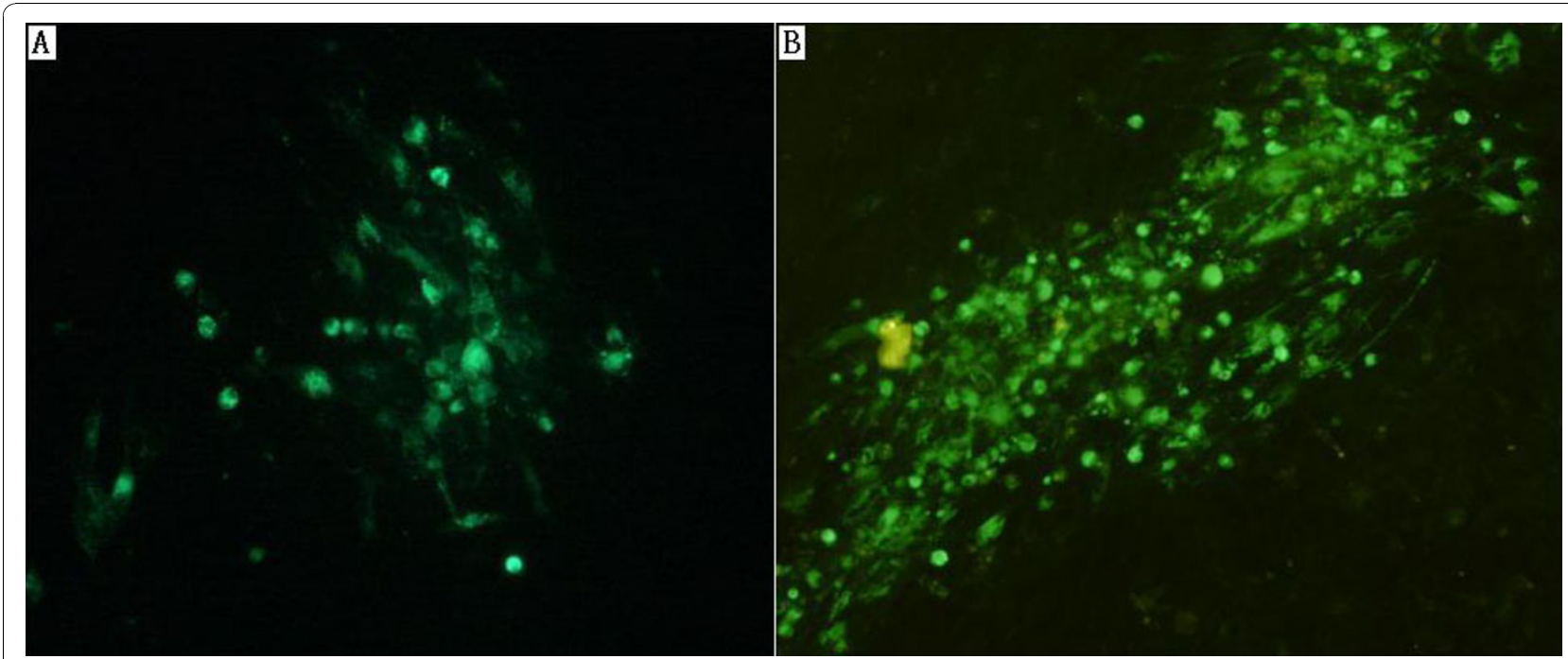

Figure 2 Comparison of plaque characteristic of bac-GX0101 $(A+C)$ and parental virus $G X 0101$ in $C E F$. $A$ : plaque of $G X 0101 \triangle(A+C)$; $B$ : plaque of GX0101. GX0101 and GX0101 $\triangle(A+C)$ were inoculated onto six-well plates seeded with $\mathrm{CEFs}$ and incubated at $37^{\circ} \mathrm{C}, 5 \% \mathrm{CO}_{2}$, respectively. Visible viral plaques were confirmed by IFA with monoclonal antibody H19. The plaque size of GX0101 $\Delta(A+C)$ was smaller than that of GX0101 at $96 \mathrm{~h}$ after infected in fresh CEF cells.

tumors conformed by histopathologic changes in different tissues (spleen, liver, heart, and kidney) in groups infected with GX0101 or GX0101 $\Delta(\mathrm{A}+\mathrm{C})$, respectively (Table 4). And no death was observed in the control group. These results showed that the mortality and oncogenicity of GX0101 $(\mathrm{A}+\mathrm{C})$ were lower than that of GX0101, although the difference was not significant $(\mathrm{P}>0.05)$.

\section{Immunosuppressive effects of the two viruses}

As demonstrated in Table 5, hemagglutination inhibition (HI) antibody titers to AIV-H9 in birds infected with GX0101 $\Delta(A+C)$ or GX0101 were significantly lower than that of the control birds $(\mathrm{P}<0.05)$. Between the two viruses, HI antibody titers to AIV-H9 in birds infected with GX0101 were significantly lower than that

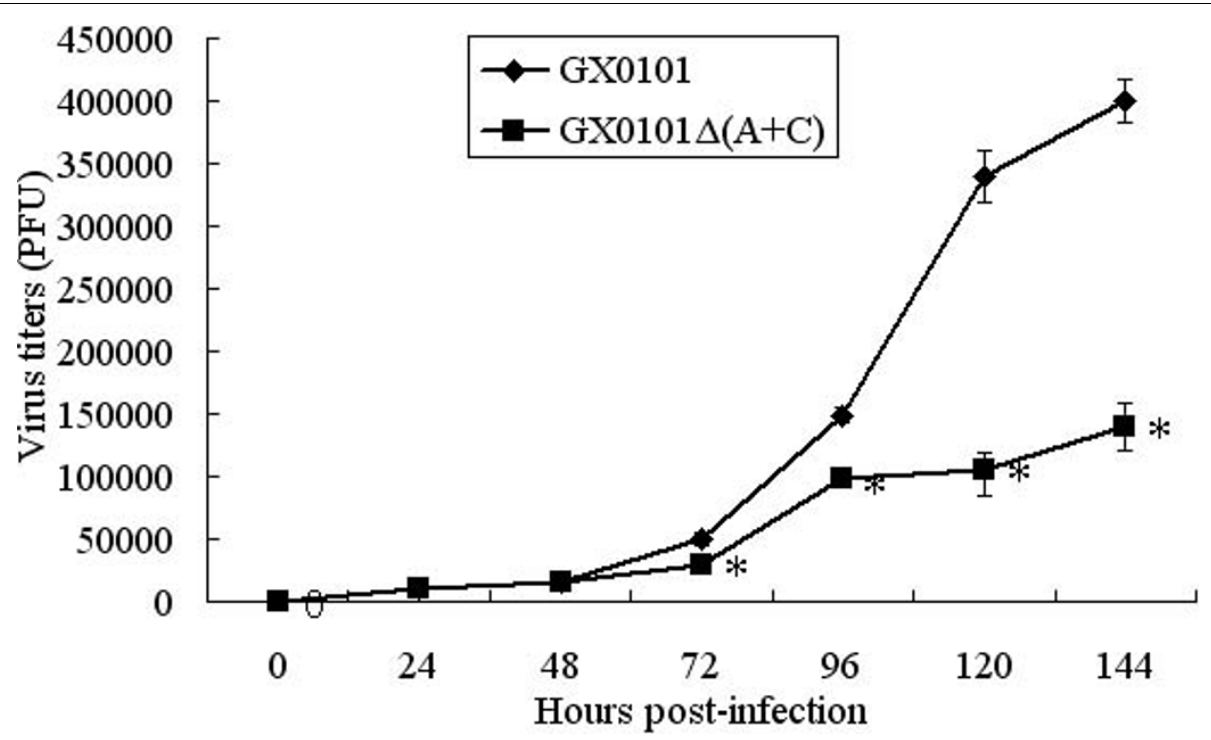

Figure 3 Growth curves of GX0101 $\triangle(A+C)$ and GX0101 in vitro. 100 PFU GX0101 and $G X 0101 \triangle(A+C)$ were inoculated onto six-well plates seeded with $2 \times 10^{6} \mathrm{CEFs}$ and incubated at $37^{\circ} \mathrm{C}, 5 \% \mathrm{CO}_{2}$, respectively. At hours $0,24,48,72,96,120$ and 144 p.i., the infected cells were trypsinized and serial 10-fold dilutions were added onto six-well plates of CEFs, visible viral plaques were counted on days 5 p.i. by IFA. The means $\pm S D$ at each time point were shown, ${ }^{*} P<0.05$ compared with those in GX0101 group. It was demonstrated that the mutant virus GX0101 $\triangle(A+C)$ exhibited a decreased replication ability in CEF compared with GX0101 at hours 72, 96, 120 and 144 p.i. $(P<0.05)$. 
Table 1 Comparision of viremia levels between GX0101 and $G X 0101 \Delta(A+C)$ infected SPF chickens $(n=10)$

\begin{tabular}{lll}
\hline Days post inoculation & \multicolumn{2}{l}{ Viremia (PFU/ml) } \\
\cline { 2 - 3 } & GX0101 & GX0101 $\mathbf{A}(\mathbf{A}+\mathbf{C})$ \\
\hline 7 & $156.5 \pm 40.5 \mathrm{a}$ & $123.8 \pm 27.3 \mathrm{a}$ \\
14 & $475.8 \pm 55 \mathrm{a}$ & $255.0 \pm 39.5 \mathrm{~b}$ \\
21 & $1567.4 \pm 253.6 \mathrm{a}$ & $455.4 \pm 98.7 \mathrm{~b}$ \\
28 & $1244.3 \pm 242.6 \mathrm{a}$ & $513.4 \pm 188.9 \mathrm{~b}$ \\
\hline
\end{tabular}

The numbers in the table indicate: mean \pm standard deviation. The same letters following values indicate that the differences were not significant $(\mathrm{P}>$ $0.05)$ between treatments at each time. The different letters following values indicate that the differences were significant $(P<0.05)$ between treatments at each time.

of birds infected with $\mathrm{GX0101 \Delta}(\mathrm{A}+\mathrm{C})(\mathrm{P}<0.05)$. However, HI antibody titers to AIV-H5 and NDV, GX0101 showed stronger immunosuppressive effects than GX0101 $\Delta(A+C)$, although the difference was not statistically significant $(\mathrm{P}>0.05)$.

\section{Discussion}

It was reported that CAT activity under the control of the bi-directional promoter was only detected in MDVinfected CEF but not in uninfected CEF when transfected with CAT reporter plasmids, indicating that the bi-directional promoter requires either viral or MDVinfection related cellular factors for regulation [17]. In the previous reports, we found that the activity of bidirectional promoter in the direction of the $1.8-\mathrm{kb}$ mRNA was higher than that in the direction of the pp38, and the CAT activity was significantly lower but not disappeared in a pp38 deletion virus than in the parental virus [8-10]. This suggested that pp38 plays an important role in regulating the transcriptional activity of the bi-directional promoter, but that an additional factor may also be necessary. In this study, CAT gene was used as a reporter to investigate the influence of 1.8-kb mRNA on its upstream bi-directional promoter. The results showed that the CAT expression level of

Table 2 Comparision of CAT expression levels under the promoter in opposite directions in GX0101ه(A+C)-CEF or GX0101-CEF ( $\mathbf{n}=\mathbf{5}$ )

\begin{tabular}{|c|c|c|c|}
\hline \multirow[b]{2}{*}{$\begin{array}{l}\text { Transfected } \\
\text { plasmids }\end{array}$} & \multicolumn{3}{|l|}{ Transfected CEF } \\
\hline & 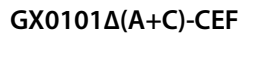 & GX0101-CEF & CEF \\
\hline $\begin{array}{l}\text { pP(pp38)- } \\
\text { CAT }\end{array}$ & $0.069 \pm 0.013 b$ & $0.413 \pm 0.045 a$ & $0.002 \pm 0.0002 c$ \\
\hline $\begin{array}{l}\text { pP(1.8-kb)- } \\
\text { CAT }\end{array}$ & $0.073 \pm 0.024 b$ & $0.505 \pm 0.068 a$ & $0.001 \pm 0.0004 c$ \\
\hline Control & $0.000 \pm 0.000 a$ & $0.000 \pm 0.000 a$ & $0.000 \pm 0.000 a$ \\
\hline
\end{tabular}

The numbers in the table indicate: mean \pm standard deviation of five replicate assays with a given reporter plasmid. The same letters following values indicate that the differences were not significant $(P>0.05)$ between treatments. The different letters following values indicate that the differences were significant $(P<0.05)$ between treatments.
$\mathrm{GX} 0101 \Delta(\mathrm{A}+\mathrm{C})-\mathrm{CEF}$ was significantly lower than that in GX0101-CEF transfected with two CAT reporter plasmids under the control of the bi-directional promoter in two opposite oppositions. These results suggested that 1.8-kb mRNA was necessary in addition to pp38 for transcriptional activity of the bi-directional promoter. However, either pp38 or $1.8-\mathrm{kb}$ mRNA did not fully affect the promoter activity, respectively. Our future studies will focus on the construction of pp38- and 1.8-kb mRNA-deleted virus, it may help to examine whether the activity of the promoter will be fully removed after both pp38 and 1.8-kb mRNA were deleted.

Following deletion of $\operatorname{ORF}(\mathrm{A}+\mathrm{C})$, we found that the replication ability of $\mathrm{GX} 0101 \Delta(\mathrm{A}+\mathrm{C})$ was decreased compared to that of GX0101 in vitro and in vivo. MDV replication origin locates between pp38 and $1.8-\mathrm{kb}$ mRNA in the long inverted repeat region of the viral genome, therefore, we speculate that $1.8-\mathrm{kb}$ mRNA might affect the MDV replication origin as its effect to the bi-directional promoter. However, further studies are required to confirm this hypothesis and to understand the mechanism of 1.8-kb mRNA.

Although GX0101 $\Delta(A+C)$ was severely impaired for in vivo replication, the virus retained a low level of oncogenicity and thus demonstrated that $1.8-\mathrm{kb}$ mRNA was dispensable for tumor induction. Meanwhile, HI antibody titers to AIV-H9, AIV-H5 and NDV in birds infected with GX0101 were lower than those infected with $\mathrm{GX0101 \Delta}(\mathrm{A}+\mathrm{C})(\mathrm{P}<0.05)$. The differences in tumor induction or immunosuppression effects between $\mathrm{GX0101 \Delta}(\mathrm{A}+\mathrm{C})$ and $\mathrm{GX0101}$ may be due to the poor replication ability in vivo of $\mathrm{GX0101 \Delta}(\mathrm{A}+\mathrm{C})$.

\section{Conclusion}

These results suggested that the $1.8-\mathrm{kb}$ mRNA gene family did not directly influence the oncogenesis of MDV but related to its replication ability. And our future studies will concentrate on the identification of the $1.8-\mathrm{kb}$ mRNA product and its mechanism.

\section{Methods}

\section{Virus and Plasmid}

A field virulent MDV strain, named GX0101, was isolated from a layer farm in Guangxi province in China [14]. In our previous study, a full-length infectious BAC clone of GX0101 strain and Escherichia coli EL250 (harboring the GX0101-BAC containing the whole genome of GX0101) were constructed [15,16].

The recombinant plasmids expressing chloramphenicol acetyltransferase (CAT) gene under the control of the bi-directional promoter were constructed in our laboratory [9]. In the recombinant plasmid $\mathrm{pP}(\mathrm{pp} 38)$ CAT, CAT was expressed under the promoter in pp38 direction, and in the recombinant plasmid $\mathrm{pP}(1.8-\mathrm{kb})$ - 
Table 3 Comparisons of growth rates of birds challenged with GX0101 $(A+C)$ or GX0101

\begin{tabular}{|c|c|c|c|}
\hline \multirow[t]{2}{*}{ Weeks post inoculation } & \multicolumn{3}{|l|}{ Groups } \\
\hline & Control & $G X 0101 \Delta(A+C)$ & GX0101 \\
\hline 3 & $117.91 \pm 9.40(13) \mathrm{a}$ & $111.62 \pm 18.62(34) \mathrm{a}$ & $117.88 \pm 17.63(33) \mathrm{a}$ \\
\hline 4 & $189.17 \pm 18.44(13) \mathrm{a}$ & $175.74 \pm 33.62(34) \mathrm{a}$ & $174.84 \pm 32.44(31) \mathrm{a}$ \\
\hline 5 & $275.42 \pm 30.34$ (13) a & $243.24 \pm 46.9$ (34) b & $233.83 \pm 51.82(30) b$ \\
\hline 6 & $401.25 \pm 41.24(13) \mathrm{a}$ & $335.61 \pm 62.71$ (33) b & $309.66 \pm 91.74(29) b$ \\
\hline 8 & $672.92 \pm 72.53$ (13) a & $571.72 \pm 102.58(32) b$ & $510.19 \pm 155.27(26) b$ \\
\hline
\end{tabular}

The numbers in the table indicate: mean \pm standard deviation. Different letters indicate that the differences were significant $(P<0.05)$ between treatments at each time.

CAT, CAT was expressed under the promoter in $1.8-\mathrm{kb}$ direction.

\section{Construction of GX0101 $\Delta(A+C)-B A C$}

Replacement of the ORF $(A+C)$ with the $\mathrm{Kan}^{\mathrm{R}}$ gene was carried out by a procedure of homologous recombination [16]. Electrocompetent cells were prepared from Escherichia coli EL250 (harboring the GX0101-BAC) grown at $30^{\circ} \mathrm{C}$ in Luria-Bertani (LB) medium containing chloramphenicol $(25 \mathrm{mg} / \mathrm{ml})$ to an optical density (OD600) of 0.6. The expression of recE, recT, and $\lambda$ gam was induced by $42^{\circ} \mathrm{C}$ for $15 \mathrm{~min}$. $\mathrm{Kan}^{\mathrm{R}}$ cassette flanked by FRT sites was amplified using primers $1.8-\mathrm{kb}$ mRNA $(\mathrm{A}+\mathrm{C})-\mathrm{kan}^{\mathrm{R}}-\mathrm{F}$ and 1.8-kb mRNA $(\mathrm{A}+\mathrm{C})-\mathrm{kan}^{\mathrm{R}}-\mathrm{R}$ (Table 6) from pKD13 [18]. About $300 \mathrm{ng}$ of the PCR products were electroporated into $50 \mu \mathrm{l}$ of electrocompetent EL250 cells harboring the GX0101-BAC using standard electroporation parameters $(2.0 \mathrm{KV}, 200 \Omega$ and $25 \mu \mathrm{F}$ ), and recombinant clones were isolated and examined for insertion of $\mathrm{kan}^{\mathrm{R}}$ into the right locus using PCR. Once individual clones were examined and confirmed to lack spurious changes, $\operatorname{kan}^{\mathrm{R}}$ was excised by induction of FLP recombination by incubation in LB medium containing $0.02 \%$ arabinose for $12 \mathrm{~h}$. In order to delete the second $\mathrm{ORF}(\mathrm{A}+\mathrm{C})$ copy, the entire procedure was repeated. Once both copies were deleted, an

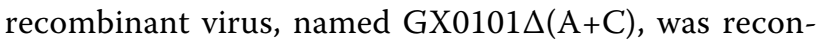
stituted by transfecting CEF cultures with purified BAC DNA. And the recombinant virus, in which one copy

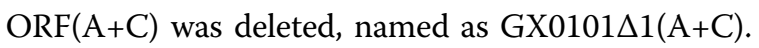

\section{Confirmation of the deletion of $\operatorname{ORF}(\mathrm{A}+\mathrm{C})$}

The deletion of the $\operatorname{ORF}(A+C)$ from the GX0101 BAC DNA were analyzed by PCR using primers, which cross the 1.8-kb mRNA ORF $(A+C)$, as follows: forward primer,

Table 4 Comparison of the mortality and oncogenicity in SPF chickens

\begin{tabular}{lll}
\hline Strain & Mortality (\%) & Oncogenicity (\%) \\
\hline GX0101 & $20 / 40(50.0)$ & $9 / 40(22.5)$ \\
GX0101 $\triangle(A+C)$ & $16 / 40(40.0)$ & $5 / 40(12.5)$ \\
Control & $0 / 13(0)$ & $0 / 13(0)$ \\
\hline
\end{tabular}

5'-GGCTAGCATTCGATAAGC-3'; reverse primer, 5'-GGAGGTGTAATATAAGG G-3'. GX0101 $\Delta(\mathrm{A}+\mathrm{C})$ was reconstituted by transfecting CEF cultures with purified BAC DNA as previously described [15]. When CEF started to show plaques, the cells were passed by trypsinization. The virus-containing cells were passed 3 to 4 rounds for enrichment of infectious clone virus GX0101 $\Delta(A+C)$. Finally, the cells infected with GX0101 $(\mathrm{A}+\mathrm{C})$ were harvested and stored in liquid nitrogen.

After transfection of the mutant viruses into CEF cultures, we compared the plaques of $G X 0101 \Delta(A+C)$ with those of GX0101 by immunofluorescence analysis (IFA) with monoclonal antibody $\mathrm{H} 19$ at $96 \mathrm{~h}$ after infected in fresh CEF cells as previously described [19] with modifications. Briefly, infected cells were washed with PBS and fixed with ethanol:acetone solution (4:6) at room temperature for $10 \mathrm{~min}$. After removing fixing solution, the cells were air dried, and incubated with H19 (1:1000) for $1 \mathrm{~h}$ at $37^{\circ} \mathrm{C}$. Following three washes with PBS, the cells were incubated with goat anti mouse FITC labeled secondary antibodies (Sigma) for $1 \mathrm{~h}$. Cells were further washed three times with PBS and examined under a fluorescence microscope.

In vitro and in vivo replication of $\mathrm{GX0101 \Delta}(\mathrm{A}+\mathrm{C})$

The rates of growth in vitro of GX0101 $\Delta(A+C)$ were measured as follows, briefly, 100 PFU GX0101 and $\mathrm{GX0101 \Delta}(\mathrm{A}+\mathrm{C})$ (from stock virus in liquid nitrogen) were inoculated onto six-well plates seeded with $2 \times 10^{6}$ CEFs and incubated at $37^{\circ} \mathrm{C}, 5 \% \mathrm{CO}_{2}$, respectively. At hours $0,24,48,72,96,120$ and 144 p.i., the infected

Table 5 Influence of GX0101 $(A+C)$ and GX0101 virus infections on HI antibody titers to NDV, AIV-H5 and AIV$\mathrm{H} 9$ after vaccination

\begin{tabular}{llll}
\hline Strain & HI titers (log2) & & \\
\cline { 2 - 4 } & NDV & AIV-H5 & AIV-H9 \\
\hline GX0101 & $9.71 \pm 1.46(28) b$ & $4.45 \pm 2.92(28) b$ & $3.48 \pm 2.06(28) \mathrm{c}$ \\
GX0101 $\triangle(A+C)$ & $10.07 \pm 1.23(33) a$ & $5.63 \pm 2.77(33) b$ & $5.50 \pm 2.39(33) b$ \\
Control & $10.57 \pm 0.76(13) a$ & $7.15 \pm 1.41(13) a$ & $7.00 \pm 1.41$ (13)a \\
\hline
\end{tabular}

The numbers in the table indicate: mean \pm standard deviation. Different letters indicate that the differences were significant $(P<0.05)$ between treatments. 
Table 6 List of primers used for the deletion of ORF $A$ and $C$

\begin{tabular}{|c|c|}
\hline Primers & Sequence $5^{\prime}-3^{\prime}$ \\
\hline $\begin{array}{l}\text { 1.8-kb mRNA } \\
(\mathrm{A}+\mathrm{C})-\mathrm{kan}^{\mathrm{R}}-\mathrm{F}\end{array}$ & $\begin{array}{l}\text { 5'-aaaggatctcaattaatagaacggcgattttttatttacggcgatatttg } \\
\text { CGTGTAGGCTGGAGCTGCTTC }{ }^{a}-3^{\prime}\end{array}$ \\
\hline $\begin{array}{l}\text { 1.8-kb mRNA } \\
(A+C)-k^{R}-R\end{array}$ & $\begin{array}{l}5^{\prime} \text {-aaacagtttctaatcgaaagcgttaccgaacttgtctttaatgagaatcc } \\
\text { CATCCGGGGATCCGTCGAC -3' }\end{array}$ \\
\hline
\end{tabular}

${ }^{a}$ For primers $1.8-\mathrm{kb}(\mathrm{A}+\mathrm{C})-\mathrm{kan}^{\mathrm{R}}-\mathrm{F}, 1.8-\mathrm{kb}(\mathrm{A}+\mathrm{C})-\mathrm{kan}^{\mathrm{R}}-\mathrm{R}$, underlined sequences indicate the sequences from pKD13 used to amplify the $\operatorname{Kan}^{R}$ gene cassete with FRT, and sequences in bold indicate MDV sequence flanking the ORF $(A+C)$.

cells were trypsinized and serial 10 -fold dilutions were added onto six-well plates of CEFs, visible viral plaques were counted on days 5 p.i. by IFA.

In vivo replication of $\mathrm{GX} 0101 \Delta(\mathrm{A}+\mathrm{C})$ were measured as follows. In brief, blood samples in anticoagulants were collected from 10 birds of each group on days 7 , 14, 21 and 28 p.i., and $1 \mathrm{ml}$ blood from each bird was mixed with $9 \mathrm{ml}$ DMEM. Blood suspensions were centrifuged for $5 \mathrm{~min}$ at $500 \mathrm{~g}$ to separate white blood cells. And $500 \mu \mathrm{l}$ white blood cells $\left(10^{6} \mathrm{cells} / \mathrm{ml}\right)$ collected after centrifugation were used to inoculate two duplicate 35-mm plates with CEF monolayer. To determine viremia levels, visible viral plaques were counted on days 5 p.i. by IFA.

\section{Determination of CAT activity in GX0101-CEF and GX0101 $(\mathrm{A}+\mathrm{C})$-CEF}

To analyze the transcriptional activity of the bi-directional promoter in GX0101 $\Delta(A+C)$ infected CEF, plasmids $\mathrm{pP}(\mathrm{pp} 38)$-CAT and $\mathrm{pP}(1.8-\mathrm{kb})$-CAT were used to transfect GX0101-CEF or GX0101 $(\mathrm{A}+\mathrm{C})$-CEF, respectively. Construction of recombinant plasmids expressing CAT gene under the control of the bi-directional promoter was performed as previously described [9]. Briefly, the bi-directional promoter sequences were amplified by PCR, and the PCR products were inserted into PCATBasic vector (Promega) at the KpnI and SacI sites. In the recombinant plasmids, $\mathrm{pP}(\mathrm{pp} 38)$-CAT and $\mathrm{pP}(1.8$ $\mathrm{kb})$-CAT, CAT was expressed under the regulation of the promoter in opposite directions. Transfection of recombinant plasmid DNA was performed as previously described, and all dishes were incubated at $37^{\circ} \mathrm{C}$ in a $\mathrm{CO}_{2}$ incubator [9]. The expression of CAT was determined $48 \mathrm{~h}$ after transfection. The transfected CEF were harvested and resuspended in $500 \mu \mathrm{l}$ lysis buffer per 35 $\mathrm{mm}$ dish, and samples were centrifuged for $5 \mathrm{~min}$ at $10,000 \mathrm{rpm}$. Aliquots of the supernantants were detected with CAT ELISA Kit (Roche).

\section{Pathogenicity of GX0101 and GX0101 $(A+C)$}

One-day-old male SPF chickens were randomly divided into three groups and kept in three isolators under positive filtered air. In the experiment, 40 birds were inoculated intra-abdominally with 1000 PFU of GX0101 or GX0101 $\Delta(A+C)$. A control group of 13 birds was inoculated with uninfected CEF. During 120 days after challenge with the two viruses, all chickens were examined for gross MD lesions. Body weight measurements of the birds in different groups were made on weeks 3 , 4, 5, 6 and 8 p.i., in order to evaluate the effect of the two viruses on chicken growth rates.

\section{Immunosuppressive effects of the GX0101 and GX0101 $\Delta(A+C)$}

In order to evaluate the immunosuppressive effects of the two viruses, on one-day-old, chickens were inoculated intra-abdominally with 1,000 PFU of GX0101 or GX0101 $\Delta(A+C)$, while control chickens were inoculated with uninfected CEF cultures. On days 9 p.i., all chickens from each treatment were vaccinated with inactive Newcastle disease virus (NDV), H5 avian influenza viruses (AIV) and H9 AIV. On days 28 p.i., the birds' serums were collected to measure the $\mathrm{HI}$ antibody titers to NDV, AIV-H5 and AIV-H9.

\section{Acknowledgements}

This work was supported by National Natural Science Foundation of China (Grant number: 30700596). We wish to thank Dr. Blanca Lupiani for her editorial assistance.

\section{Author details}

${ }^{1}$ Animal Science and Technology College, Shandong Agricultural University, Tai'an, Shandong 271018, China. ${ }^{2}$ The Institute of Animal Science, Chinese Academy of Agricultural Sciences, Beijing 100193, China. ${ }^{3}$ Shanghai Veterinary Research Institute, Chinese Academy of Agricultural Sciences, Shanghai, 200241, China. ${ }^{4}$ China Institute of Veterinary Drug Control, Beijing 100081, China

\section{Authors' contributions}

AJS and YPL carried out most of the experiments and wrote the manuscript. JBD and ZZC carried out study design, and revised the manuscript. JYW, SS and $\mathrm{HJC}$ helped in vivo experiments, participated data organization and statistical analysis. HFZ helped in revision of the manuscript. All authors read and approved the final manuscript.

\section{Competing interests}

The authors declare that they have no competing interests.

Received: 11 August 2010 Accepted: 29 October 2010

Published: 29 October 2010

\section{References}

1. Schat KA, Calnek BW, Fabricant J: Characterisation of two highly oncogenic strains of Marek's disease virus. Avian Pathol 1982, 11:593-605.

2. Witter RL: Increased virulence of Marek's disease virus field isolates. Avian Dis 1997, 41:149-163.

3. Lee LF, Wu P, Sui D, Ren D, Kamil J, Kung HJ, Witter RL: The complete unique long sequence and the overall genomic organization of the GA strain of Marek's disease virus. Proc Natl Acad Sci USA 2000, 97:6091-6096.

4. Tulman ER, Afonso CL, Lu Z, Zsak L, Rock DL, Kutish GF: The genome of a very virulent Marek's disease virus. J Virol 2000, 74:7980-7988.

5. Lupiani B, Lee LF, Cui X, Gimeno I, Anderson A, Morgan RW, Silva RF, Witter RL, Kung HJ, Reddy SM: Marek's disease virus-encoded Meq gene is involved in transformation of lymphocytes but is dispensable for replication. Proc Natl Acad Sci USA 2004, 101:11815-11820. 
6. Brown AC, Baigent SJ, Smith LP, Chattoo JP, Petherbridge LJ, Hawes $P$, Allday MJ, Nair V: Interaction of MEQ protein and C-terminal-binding protein is critical for induction of lymphomas by Marek's disease virus. Proc Natl Acad Sci USA 2006, 103:1687-1692.

7. Reddy SM, Lupiani B, Gimeno IM, Silva RF, Lee LF, Witter RL: Rescue of a pathogenic Marek's disease virus with overlapping cosmid DNAs: use of a pp38 mutant to validate the technology for the study of gene function. Proc Natl Acad Sci USA 2002, 99:7054-7059.

8. Ding J, Cui Z, Lee LF: Marek's disease virus unique genes pp38 and pp24 are essential for transactivating the bi-directional promoters for the 1.8 kb mRNA transcripts. Virus Genes 2007, 35:643-650.

9. Ding J, Cui Z, Lee LF, Cui X, Reddy SM: The role of pp38 in regulation of Marek's disease virus bi-directional promoter between pp38 and 1.8-kb mRNA. Virus Genes 2006, 32:193-201.

10. Ding J, Cui Z, Jiang S, Li Y: Study on the structure of heteropolymer pp38/pp24 and its enhancement on the bi-directional promoter upstream of pp38 gene in Marek's disease virus. Sci China C Life Sci 2008, 51:821-826.

11. Silva RF, Gimeno I: Oncogenic Marek's disease viruses lacking the 132 base pair repeats can still be attenuated by serial in vitro cell culture passages. Virus Genes 2007, 34:87-90.

12. Bradley G, Hayashi M, Lancz G, Tanaka A, Nonoyama M: Structure of the Marek's disease virus BamHI-H gene family: genes of putative importance for tumor induction. J Virol 1989, 63:2534-2542.

13. Peng F, Bradley G, Tanaka A, Lancz G, Nonoyama M: Isolation and characterization of CDNAs from BamHI-H gene family RNAs associated with the tumorigenicity of Marek's disease virus. J Virol 1992 66:7389-7396.

14. Zhang Z, Cui Z: Isolation of recombinant field strains of Marek's disease virus integrated with reticuloendotheliosis virus genome fragments. $\mathrm{SCi}$ China C Life Sci 2005, 48:81-88.

15. Sun AJ, Petherbridge L, Zhao YG, Li YP, Nair V, Cui ZZ: A BAC clone of MDV strain GX0101 with REV-LTR integration retained its pathogenicity. Chinese Sci Bull 2009, 54:2641-2647.

16. Sun AJ, Xu XY, Petherbridge L, Zhao YG, Nair V, Cui ZZ: Functional evaluation of the role of reticuloendotheliosis virus long terminal repeat (LTR) integrated into the genome of a field strain of Marek's disease virus. Virology 2010, 397:270-276.

17. Shigekane H, Kawaguchi Y, Shirakata M, Sakaguchi M, Hirai K: The bidirectional transcriptional promoters for the latency-relating transcripts of the pp38/pp24 mRNAs and the $1.8 \mathrm{~kb}$-mRNA in the long inverted repeats of Marek's disease virus serotype 1 DNA are regulated by common promoter-specific enhancers. Arch Virol 1999, 144:1893-1907.

18. Datsenko KA, Wanner BL: One-step inactivation of chromosomal genes in Escherichia coli K-12 using PCR products. Proc Natl Acad Sci USA 2000, 97:6640-6645.

19. Lee LF, Liu X, Witter RL: Monoclonal antibodies with specificity for three different serotypes of Marek's disease viruses in chickens. J Immunol 1983, 130:1003-1006

doi:10.1186/1743-422X-7-294

Cite this article as: Sun et al:: Deletion of 1.8-kb mRNA of Marek's disease virus decreases its replication ability but not oncogenicity. Virology Journal 2010 7:294.

\section{Submit your next manuscript to BioMed Central and take full advantage of:}

- Convenient online submission

- Thorough peer review

- No space constraints or color figure charges

- Immediate publication on acceptance

- Inclusion in PubMed, CAS, Scopus and Google Scholar

- Research which is freely available for redistribution 